\title{
PROLES SINE MATRE CREATA: THE PROMETHEAN URGE IN THE HISTORY OF THE HUMAN BODY IN THE WEST
}

\author{
Luis Montiel \\ Historia de la Medicina. Facultad de Medicina. Universidad Complutense de Madrid \\ montiel@med.ucm.es
}

Received: 12 June 2012; Accepted: 15 October 2012.

Citation/ Cómo citar este artículo: Montiel, Luis (2013), "Proles sine matre creata: The Promethean Urge in the History of the Human Body in the West", Asclepio, 65 (1): p001. doi: http://dx.doi.org/10.3989/asclepio.2013.01

\begin{abstract}
Since the beginning of modernity there has been an observable tendency in Western thought to consider the human body as susceptible of technical manipulation, to the extreme of conceiving the possibility of manufacturing it. The figures of the homunculus and the automaton, the heirs of the Golem, represent the clearest embodiment of this aspiration. This paper explores the psychology underlying this plan, based on the psychological theory of C.G. Jung, and developed more recently by J. Hillman, on the hypothesis that the plan involves the denial of the feminine and, therefore, of the more truly psychological aspects of humanity, in the name of a unilaterally rationalistic and materialistic worldview. From the viewpoint of the authors mentioned, the mythicalpsychological reference capable of providing the fundamental key to this project would be Prometheus.
\end{abstract}

KEYWORDS: Idea of the body; Archetypal psychology; Golem; Homunculus; Automaton.

\section{PROLES SINE MATRE CREATA: EL ANHELO PROMETEICO EN LA HISTORIA DEL CUERPO HUMANO EN OCCIDENTE}

RESUMEN: Desde los inicios de la modernidad puede detectarse en el pensamiento occidental una tendencia a pensar el cuerpo humano como susceptible de manipulación técnica, hasta el extremo de concebir la posibilidad de fabricarlo. Las figuras del homúnculo y el autómata, herederas de la del gólem, representan las cristalizaciones más evidentes de esta pretensión. El presente trabajo pretende explorar la psicología que está en la base de este designio a partir de la teoría psicológica de C.G. Jung desarrollada más recientemente por J. Hillman, sobre la hipótesis de que dicho proyecto implica la negación de lo femenino y, con ello, de los aspectos más propiamente psíquicos de lo humano, al servicio de una cosmovisión unilateralmente racionalista y materialista. El referente mítico -psicológico, en la perspectiva de los autores mencionados- capaz de suministrar las claves profundas de ese proyecto sería Prometeo.

PALABRAS CLAVE: Idea del cuerpo; Psicología arquetipal; Gólem; Homúnculo; Autómata.

Copyright: (C) 2013 CSIC. This is an open-access article distributed under the terms of the Creative Commons AttributionNon Commercial (by-nc) Spain 3.0 License. 


\section{INTRODUCTION}

In three studies published over the past few years (Montiel 2008a y b, 2010) I have taken a closer approach to a psychological attitude that I have temporarily called "Promethean urge," (Montiel, 2010, p.29) ${ }^{1}$ which has become notoriously apparent throughout western modernity, ${ }^{2}$ especially since the dawn of Renaissance, and whose elucidation I find particularly important in as far as it deals with the image of the human being that it depicts. Such conception of the human nature will have an evident effect on the way of understanding the medical practice, but also on any other aspect of existence, from work to politics or even the most intimate interpersonal relationships. Hence, I attach great importance to this analysis.

Briefly synthesizing what was exposed in those studies, I will say that, starting in the Renaissance, but rooted in the late Middle Ages, came to light unreal figures that would later become legendary; first of all, the golem of the cabbalists and, almost simultaneously, the homunculus of some Western alchemists; also, some time later, especially through medicine, the automaton, the man-machine. Unreal, I said, which is only valid from a historical perspective, since the automaton has ended up acquiring a material reality, and who knows what may happen with the homunculus in a future of genetic engineering. But the fact that matters is that, in their genesis, these figures were mere dreams, just expressions of an urge, a wish, a pretension. Those who dreamt of the homunculus and the golem did not succeed in creating them, and the creators of automatons only slowly approached their objective without actually concluding it. For that reason I claim that it is a dream, something that has to do mostly, maybe exclusively, with psychology, i.e., an individual and collective psychology, given its permanence in the common imaginary and in its cultural manifestations, especially in literature and, more recently, in cinema.

In the pages that follow I will try to identify the deep psychological substratum of this Promethean urge by starting, as seems logical, from the myth that appears to be its basis: the Promethean myth, the titan who is a friend of humans. ${ }^{3}$ Or was it just an enemy of the Gods?

Just the proposal of the objective will be enough for whoever is familiarized with the so-called "imaginal psychology" of James Hillman to understand that my approach to this matter is in debt with his own methodological proposals, which implies a similar debt with the works of Carl Gustav Jung. In particular I will take as a starting point for my analysis this statement by the U.S. author:

For us history is a psychological field in which fundamental patterns of the psyche stand out; history reveals the fantasies of the makers of history, and at their back and within the fantasies and patterns are the archetypes (Hillman, 1972, pp. 126-127).

Note that with the expression "the makers of history" Hillman does not refer to historians, but to its actors; besides, what is claimed in these lines must not be interpreted in a reductionist sense, "History is only...;" we must not overlook either his "for us," that is, the experts in psychology, present in the quotation. It implies, then, a methodological perspective, which I will apply to the issue at hand.

\section{PROMETHEUS: PROCREATION WITHOUT A MOTHER}

The Promethean myth has been studied from a Jungian perspective by the author mentioned in the second endnote of this article. She goes as far as to suggest a "Promethean Syndrome", and she also deals with the myth of the Golem and Goethe's Faust, as I will do myself, which would seem to agree with my own proposal. I hasten to add, however, that that is not the case. I have enormously benefited from the reading of her book, but both the materials and focus of my analysis are naturally different, given the chronological distance that separates both studies (19792011), as well as the starting point and orientation of the investigation; hers from the analytical psychology, mine from the history of medical thinking ${ }^{4}$ and its repercussion in literature. However, I will certainly resort to that same psychology, as I will show later. Bettina Knapp presents the myth of Prometheus as a metaphor for the "birth and development of the individual's ego", an assertion I am fully in line with, and develops her analysis in the perfectly legitimate sense of the search for the "ego-consciousness" and the "self-consciousness" - "self" as the English translation of the Jungian Selbst- (Knapp, pp. 4-5).

But in my opinion, both the myth and what, in Hillman's terms, we could call an archetypal image has further potential. In that line I intend to study the most negative aspects of that "syndrome" identified by Knapp, in some way pathologic, although without losing sight of Hillman's radically new approach, i.e., that the pathological in this field is not, from the point of view of dynamic psyche, only negative, since it represents a way of soul-making, ${ }^{5}$ the hard core of his psychological theory and his particular turn of the screw to C.G. Jung's contributions to psychology. ${ }^{6}$

As practically all the mythical figures in ancient Greece, Prometheus is the protagonist in different stories, all of which share, however, one aspect in common which, so to speak, constitutes the essential feature of this character: the theft of fire from the Olympic Gods to give it to human beings. These would be originally failed creatures, created by him out of mud. However, thanks to his gift, they could, on the one hand, beco- 
me the lords of nature by means of technique, and, on the other hand, have something - sacrifices- with which to negotiate with the Olympics and free themselves from their annihilation, planned by Zeus. The interesting aspect of this character, from the point of view I propose, is that an explicitly male figure is responsible for the creation of the human lineage, both in its material traits, and its divine, spiritual ones. A history of humankind - a sacred history at this levelstarts with Prometheus. It is a history in which humankind is, borrowing a well-known quotation from Ovid's Metamorphoses, proles sine matre creata.

In the most explicit way this belief appears in an excerpt of The Eumenides, by Aeschylus, quoted and commented by Hillman:

The mother is not parent of that which is called her child, but only nurse of the new-planted seed that grows. The parent is he who mounts... There can be a father without any mother (Hillman, 1972, p. 224).

It is no other than Apollo who enunciates this belief, which Aristotle's natural philosophy ${ }^{7}$ and Galen's medical thought ${ }^{8}$ will endorse, as well as other authors -up to Freud himself! (Hillman, 1972, pp. 238-243)with whom I will briefly deal later. Without leaving classical Greece and the mythical environment, it suffices to remember the birth of Athena from Zeus's head, an event in which, according to some versions, the one who acts as "midwife" - cleaving Zeus's skull with an axe- is Prometheus himself (Campbell, 1986, p. 151). But the other root of our culture does not fall short in this issue either. It is enough to remember, as Hillman does, that Yahve creates Adam, and then Eve out of his matter (Hillman, 1972, p. 217).

All this makes evident the misogynist character that, according to this author, runs through all our culture since its double origin, Hellenic and Semitic - through Christianism-; but, in the particular case of Prometheus, it is necessary to notice another hallmark, no less important, at least for the purpose of this work: the hybris, the sin par excellence for the Greeks, as well as for Christians, under the name of superbia, pride. Stealing from the Olympics is hybris, much more if the spoils of the theft fall into the hands of inferior creatures, like human beings.

Belonging to a lineage of archaic gods, the titans, Prometheus does not own the fire, the symbol of spirit, and he has to take it away from the Olympics. His creatures, the human beings, will inherit both traits from their mythical father: misogyny and hybris. And this Promethean and misogynist hybris embodied in man will be revealed in the persistence of dream, to which I have already referred: procreation without a mother, which means nothing other than the uselessness of the feminine, its conversion into something dispensable, superfluous. What successive projects -the golem, the homunculus, the automaton- hide behind their material figure is a psychological attitude of a unilateral affirmation of the masculine, rationaltechnological and Apollonian to the detriment of the factors traditionally attributed to the feminine. And these factors, or values, are the ones that give substance to the Jungian archetype of anima, Hillman's privileged object of study through the myth of Eros and Psyche, which he identified, from a historic and psychological perspective, as both the traditional "soul" and the "psyche" brought to light by psychoanalysis. Due all the above, that project, which runs under the surface of all modernity until today, would have its basis in a "psychology without the soul", in the words of Jung, taken up later by Hillman. We will now contemplate its development and the figures in which it crystallizes throughout the modern period.

\section{GOLEM: IMITATIO DEI}

The emergence of legends related to both the golem and the homunculus, Jewish and Christian versions (undoubtedly heterodox, even heretical) of the psychological-technical project that I have just described, takes place in the Renaissance. However, both traditions are most likely to have their roots in the Middle Ages (Newman, 2004, pp. 173-187). The golem in particular can be traced back even further, as medieval rabbis did, since they used the word "golem" to designate the first man, Adam, in the moment prior to his animation by the divine breath:

In the Talmudic Aggadah (...) Adam is designated at certain stage in his creation as a golem. Golem is a Hebrew word which only appears once in the Bible, in psalm 139 (...) Golem probably means here, and definitely in later sources, the not configured, the formless (...) Mediaeval philosophic literature takes it as a Hebrew term to name matter, the shapeless hyle, and that poignant meaning will partially remain in successive interpretations. The Adam that has not yet been touched by the breath of God will be called golem in that sense (Scholem, 1953, pp. 238-239).

The fundamental text for the history of the golem is the Sefer Yetzirah, or Book of Creation, of undetermined dating; it seems to be a Neo-Pythagorean Jewish text composed between the third and fourth centuries. In that book, the meaning and function of "the thirty two ways to wisdom" could be studied for the first time, consisting of ten sephiroth or prime numbers, and the twenty two consonants of the Hebrew alphabet. In the myth of the creation of the Golem only letters intervene, "elements" of creation that -always according to Scholem - would represent in the Jewish thought about nature, something 
analogous, if not identical, to the Pre-Socratic elements - water, air, earth and fire-. From this perspective, the creation of a Golem by man may have a positive value, symbolizing the initiation into a hidden knowledge -the secret of creation - which man is able to reach as a privileged creature of his God. A medieval commentary of Jezirah (ca. 1200) claims that the creation of a golem symbolizes wisdom, the right understanding of the sacred books - Jezirah in particular - (Scholem, 1953, pp. 257-258); but this magic faculty is not always considered morally positive; indeed, for the already mentioned Book of Creation,

...magic wisdom is, then, a knowledge that is pure, prior to the fall, which corresponds to the human nature just because it is the image of God. [But] this opinion, which totally prevails in the commentaries, instructions and legends under study, must be strictly distinguished from the specific opinion of the Cabala about magic, as it is fundamentally found in the Zohar, in which magic appears as a faculty brought about by the fall of the first Adam; a faculty that, through decadence, through its bond to earth, from which it comes, links man to death (Scholem, 1953, p. 255).

It is not incidental either, in this domain in which words and letters enjoy such configuring power, the fact that the magic word that breathes life into the golem, in some stories engraved on his clay forehead, is emeth, meaning "truth". Likewise, when the initial aleph is erased - which in most narrations means the end of the golem's existence- the resulting word is meth, "death"(Scholem, 1953, p. 260). Discrepancy between the opinions of Jezirah and Zohar about magic, as well as this dangerous relation between truth and annihilation, make the golem a deeply ambiguous figure. From a strictly religious - not magic - point of view, the inherent risks of the act of creation of the golem were sufficiently evaluated by the medieval Talmudists: in the case of the agent that breathes life into the golem, hybris, the arrogance that violates the limits prescribed to human nature, which may lead man to consider himself not only similar, but equal to his creator; and, for that who contemplates the work of the wise man, the possibility of returning to polytheism and idolatry. In sum, the creation of the golem would represent, in a way, an extraordinary intellectual challenge, even a moral one. But, on the other hand, it entails dangers that are no less extraordinary in the domain of the spirit (Scholem, 1953, pp. 262-263).

The best-known legend of the golem stands on this tradition. It attributes the creation of one of these Promethean creatures to Rabbi Jeudah Löw ben Bezalel (1512-1609) in the end of $16^{\text {th }}$ century Prague, under the empire of Rudolph II. André Neher has studied this legend in the most remarkable manner, associating it to Faust's legend too. This is a perspective that I logically share, and that has made reading Neher's work especially important for me. However, he starts from a premise I disagree with: Faust and the golem as two new myths that lack ancestors (Neher, 1987, p. 10) ${ }^{10}$. For me, as well as for Bettina Knapp in her mentioned work, both "modern myths" are cut out of Prometheus. I think that it is this oversight of the Promethean ancestor what has led many to talk about a "Faustian" character which, indeed, as Neher himself recognizes almost unaware, would not be different from the Promethean one, except for the costume clothes of the time.

Certainly, one of this author's great achievements is, precisely, regarding temporal, historic aspects: he points out the fact that the legend of Faust - based on one or more than one real characters ${ }^{11}-$ and the legend of the golem, which includes its alleged author, the Maharal, reverential name given to the rabbi Löw (Morenu Ha-Rab Löw, "Our Teacher, Rabbi Löw.") by his adherents, are practically contemporary: the legend of Faust has its origin in the Volksbuch published in 1587, and the golem's legend began with the writing of Sefer Haniflaoth or Niflaoth Maharal, which was presumably dictated to Isaac Cohen, the rabbi's son-in-law, in 1583 (Neher, p. 11, p. 19). ${ }^{12}$

The legend of this golem explains that the rabbi created him out of mud, so that he helped him in some minor tasks; a magic word written on a piece of paper and placed between the teeth of the statue worked the prodigy. But Sabbath, the Jewish day of rest, when people should not work but engage in worship, the rabbi had to remove that piece of paper so that the mud returned to its original inert state. He forgot to do it in one occasion and the golem, gone crazy, ran around the ghetto, possessed by a destructive fury, until its creator, confronting him, wrenched the word away from him and, with it, his life.

In this figure we find associated the more or less explicitly religious traits that have already been pointed out, and a new one that very soon will be in focus, the automaton aspect of the creature:

But the most characteristic face of the golem is that of the golem-automaton. Here the approaches go beyond the monstrous vision, the hallucination or the picturesque-novelistic. They concern the ontological principles of man and his ethical, social and metaphysical problems (Neher, 1987, p. 129).

In any case, as Neher points out, in what we could call the original version of the legend, the existence of a law that is superior to human power is evident: the mission of Sabbath is to reconstruct the cosmic order while recognizing the presence of the divinity, and the 
breakthrough of the golem destroys that order ( $\mathrm{Ne}$ her, 1987, pp. 37-38). There is no hybris up to this point, but imitatio Dei at most, understood in a positive way, as a religious act (Knapp, 1979, p. 101); but the subhuman model sine matre creato is in this world and is of public domain. Other Promethean characters will aim at this objective, not to imitate God, but to be equated to him. But they will not have foreseen that they will lose their soul in the way. Neher, who never quotes Hillman nor seems to know him, writes:

The golem is mute; he is the recipient of a too-empty of soul (Neher, 1987, p. 33).

Before leaving this crystallization of the Promethean, I have to remark that, as far as I know, there is at least one feminine figure of the golem in Western culture, which a Jewish man carries out over the model of the protagonist in the novel Isabella aus Ägypten -Isabella from Egypt - by the romantic author Ludwig Achim von Arnim (1812). Would this represent an exception to the rule, an objection to the misogynous hypothesis which disregards the anima? I do not think so.

The golem Isabella has no automaton appearance, but it is an almost exact replica of the human one, in a way that gets to fool everyone. In fact, she is a golem only in the manufacturing process, so to speak, whereas she rather resembles the figure of Doppelgänger - so rampant in Romanticism - after her insertion into the world. She has been created with artful intentions, in such way that it represents the morally negative version of the authentic Isabella, and, even worse, she carries the same vices that are inherent to her creator's ethnic origin, keeping in mind that Arnim is deemed an anti-Semite:

She did not have her own will, but whatever stemmed from the thoughts of her Jewish creator, that is, pride, voluptuousness and greed (Arnim, 1982, p. 109).

It might be said that the Christian golem is quite a lot more despicable than the Jewish one, although both are made out of mud. Something similar applies to the homunculus of the alchemists. However, there is a fundamental difference between the Modern European project and its cabalistic precedent: the latter came from magic, understood as a part of religion, while the former is exclusively entrusted to techniques.

\section{HOMUNCULUS: THE EMPIRE OF THE SPIRIT}

The idea of artificially creating a human being in a laboratory, either in the magnum laboratory of nature, or in the little hearth of the alchemist, has medieval precedents that have been studied in detail in a recent work (Newman, 2004, pp. 164-187); among these precedents, the legend of the golem (Newman, 204, p. 187) stands out. However, its presence in the works of Paracelsus allows us to establish a chronological link with that other creature, explicitly subhuman, which, already in the Middle Ages, several Jewish cabalists had dreamt and claimed to have created. However, its figure, as we have just seen, will only gain authentic relevance in that same period in which Paracelsus, or any of his adherents under his name, wrote the recipe to produce a homunculus. It could also happen that the most ancient Jewish belief was found in the deepest thinking of the gentile alchemists who, among other sources, could use the cabalistic writings, to which they gained direct access, or translations ${ }^{13}$.

Paracelsus, a connoisseur of the Cabala, had a religious conception as a starting point too, but in this case a Christian notion of nature as the work of a Creator. However, this work is imperfect and is "fallen" from the original sin, as sustained by Christian religion itself, and it is a mission of the human being to help it return to its original state. Paracelsus was certain that the instrument of that creation was alchemy, the art of transmuting substances, and it was surely the union of cabalistic tradition and his alchemist education what led him - or someone who signed under his name, which seems most probable today - to suggest again the creation of human life by technical means. The recipe for the creation of a homunculus is found in a probably apocryphal text (Wyder, 2005, p. 58) ${ }^{14}$ entitled De natura rerum. This text explicitly states the ambition constituted by the object of this study:

...if it was possible that a human being was born without the need of a female body and a natural mother. I can answer that, for the Spagyrian art and for nature, this is not impossible at all, but rather completely possible (Paracelsus, 1982, Bd. 5, p. 62).

To accomplish that it is necessary to put sperm of a man in a closed retort, keep it in fermenting horse manure and let it undergo "putrefaction" for at least forty days,

...until it becomes alive, it moves and shakes, which is easy to observe. Then, it will be, to some extent, similar to a human being, but transparent, without a body. If, by this stage, he is wisely fed every day with the arcanum sanguinis humani during forty wee$\mathrm{ks}$, keeping him at a constant temperature in horse manure, he will become a living human child, with all its limbs, as any other child born out a woman, but smaller. We call him homunculus, and it must be brought up with the same devotion and care as any other child until it reaches the age of reason. This is the greatest secret that God has let mortal and sinful man know (Paracelsus, 1982, Bd. 5, p. 62). 
Notice that the sperm must be from a man; it seems obvious, but we should recall what Hillman signaled regarding the controversial role of women in conception (Hillman, 1972, pp. 217-251), as well as bear in mind that the homunculi produced in this way are always male. Besides, short before explaining the manufacturing process of the homunculus, the author referred to the generation of different monsters in nature, being the basilisk the most poisonous one. This one even has "poison hidden in its eyes," "the most toxic of all poisons," which makes him "not much different from a woman in her period, who also has a poison in her eyes" (Paracelsus, 1982, Bd. 5, p. 60).

But there is a very different approach in the Liber de homunculis, which is not about technique, but about nature, since the homunculus is not the aim of any tactic developed to that purpose, but the result of a deficiency in the human seed, which in normal circumstances -in its integrity - contains both the animal and the properly human part of the future being. The absence of the latter produces monsters, such as the homunculus, who, as a result, is more an animal than a human, since it lacks a spiritual soul. Sometimes there is not as much of an error of nature involved, but a human practice contra natura. Sodomites, for example, sometimes pour their semen inside somebody else's mouth, which produces its fermentation in the stomach, not in the womb intended to it, this being the reason for the birth of the homunculus (Paracelsus, 1982, Bd. 3, p. 434).

Therefore, the author of this text, who could be Paracelsus himself, warns in fact about the issue that is crucial in our analysis: the homunculus has no soul, and, as a result, he is a monster, an error of nature, the result of a sexual practice that is considered aberrant. And, in order to have a soul, this creature would need a womb, the feminine component. This does not represent an inversion. It does not seem that the author claims that the womb brings about the soul, but it is, at least, necessary that the being engendered with that semen is authentically human. The feminine part is necessary..$^{15}$ I will return to this shortly.

On the other hand, the homunculus is fundamentaIly an object of the author's scientific curiosity in this text, while the previous one clearly points at a more material interest, since the popular belief attributes to the imaginary creature a superhuman ability to discover hidden treasures.

It is not a matter of indifference the fact that this imaginary creature ends up having the fortune of partaking in the cast of characters of a masterpiece of modern western culture, Faust, by J. W. Goethe. In the second part of this tragedy, the doctor returns to this laboratory in the company of Mephistopheles and he finds his assistant, Wagner, engaged in the creation of a homunculus. When asked about it, he answers by making explicit the Promethean urge:

The old way of engendering is foolish for us today (...) If the animal keeps frolicking, man must, with his great gifts, have a higher origin in the future (...) What is considered mysterious in nature we dare to intelligently examine, and crystallize that which in other time let itself be organized (Goethe, 1999, p. 279).

And it certainly seems that he achieves something with his science, since a bright little creature starts to move inside the vas hermeticum, from where he speaks with his creator; but one of the first things he notices is that he does not hug him -or rather, that he does not hug the receptacle- with enough strength not to break it, since

...such is the property of things; the universe is not enough for the natural things, but the artificial ones ask for a closed space (Goethe, 1999. p. 280).

But there is a fundamental difference between the golem and the Goethean homunculus; the former is almost only matter; the term golem designates, by extension, the formless hyle that needs to be brought to life through a magic procedure, while the Homunculus, who seems to have all the spiritual capacities, needs to be incarnated and "animated", in the sense of integrating the anima, the feminine component. This is what philosopher Thales says to Proteus in the "classic Walpurgis night";

He asks for advice and yearns to be born; just like you, I understand, he is not a strange case but half born. He does not lack spiritual qualities, but a great deal of tangible properties. Until now only the glass confers weight to him, but he would like to have a body (Goethe, 1999, p. 326).

Goethe's homunculus is also different from the $\mathrm{Pa}$ racelsian one in this aspects. One could even think that the Jupiter of Weimar, in his pride and ambition, aspires to something that is even more Promethean than his Jewish and Spagyrian predecessors, that is, to create spirit before matter. But this would be a mistake. First of all, it is coherent that, in the frame of a process aimed at the essences - to the quinta essentia-, the result rather partakes of the essence, the subtle and incorporeal scope. But we must also take account of Goethe's radical attachment to the realm of tangibles. He seems to tell us, through the figure of his Homunculus that the existence - the possible existence- of a spirit without flesh is worthless. The creature itself says so when he proclaims:

I would like to be in the best sense (...) I am following the trail of two philosophers, since, sharpening my ear I heard someone scream, "Nature! Nature!" I 
would not want to separate from them, as I am sure they know the earthly essence; and so, in conclusion, I will know which way is wisest for my steps to follow (Goethe, 1999, p. 312).

The "earthly" means being "in the best sense". Therefore, the Homunculus, the objective of Wagner's enquiry, so similar to the one for which Faust himself could have lost his life, ends up being a metaphor of the reversals of science, and human ambitions in general. In order to "become in the best sense", the Homunculus must smash the retort against the chariot of the sea-nymph, Galatea, i.e., a female mythological figure, looking forward to his own authentic birth through a dark and slow evolution within the maternal waters. ${ }^{16} \mathrm{~A}$ birth in spirit, body and soul.

Notwithstanding the above considerations, it would be wrong to claim that misogyny and nightfall, if not the death of the soul, are the only outcomes that can be found in the studied stage. Alchemy itself went to the rescue of the feminine component, as is well known since Jung published, towards the end of his life, his notorious works on ars spagyrica; ${ }^{17}$ and it should be acknowledged that Goethe, in this as in other fields, has an extraordinary sensibility to detect both tendencies in his time: both the aforementioned line of thought and its opposite, which I will discuss next.

Regarding Jung's contributions, may I mention in passing some fundamental considerations; first of all, his conviction that the writings of the alchemists must be understood as descriptions of psychological processes, much more than recipes to carry out technical operations, which he explicitly sustained since Psychologie und Alchemie (1944). And, from there, his approach to that literature about the coniunctio or coincidentia oppositorum, represented precisely by the sacred marriage - hierosgamos - of the "king" and the "queen" - or the sun and the moon, or other dual symbols that represent the masculine and the feminine- whose result is the androgynous figure. It is especially interesting the fact that, as Jung remarked, some alchemists called the lapis philosophorum "the son of the widow", or "the orphan", giving special importance to the absence of a father. Without being, in this case, proles sine patre creata, it would turn out that the magnum opus they aspired to would be carried out from a mother - the earth, the prima materia (Jung, 1970, vol. 14, pp. 17-20)-

As for Goethe, we must not forget that the creator of Homunculus is the famulus, not the doctor. Faust was engaged in other business at that time. It does not seem that Wagner's achievement dazzles him, and perhaps rightly so, since we have already seen that it ends up in failure. Besides, Faust's story described by Goethe concludes with a vindication of the feminine; in fact, this tragedy finishes with two wellknown lines that claim,

\section{Das ewig Weibliche}

Zieht uns hinan. ${ }^{18}$

What happens, and that is Goethe's greatness, is that the Promethean nature of his Faust is free from misogyny, ${ }^{19}$ without thereby confronting the gods. Neher quite rightly pointed out that the introduction of the figure of Job at the beginning, in the "Prologue in Heaven", as a proto model of the bet made between God and the Devil, with the soul of Faust as a prize, raises the issue to "the highest level: the metaphysical level of a face-to-face with God" (Neher, 1987, p. 133).

In this way the radical side of the Promethean legacy was restored, but devoid of the misogynous component gained with the passage of time. A mature Goethe uses the history of the homunculus, of Homunculus, as a way of expressing his renounce to the hybris (Knapp, 1979, pp. 150-151), ${ }^{20}$ or at least that kind of hybris. Then the challenge to the divine omnipotence persists, but taken to another level, that of a bet, a game, which ultimately means acknowledging that the human being "is improvisation made flesh and history, it is the absolutely unpredictable" (Neher, 1987, p. 143).

\section{AUTOMATON: NARCISSUS ASSOCIATED TO PROME- THEUS}

The Promethean attempt to create life in a laboratory seems to come to an end with Goethe, but this will not imply giving up this project; it will simply change its methodology. There where the technique of the alchemists failed, maybe another branch of technique will succeed, and that is mechanics, which has been taking over the field in an invasive way. As I have remarked elsewhere, the predominance of anatomy over other methods of study of the human body will lead to a mechanistic understanding of it. This approach will fulfill the dream to construct an automaton as a result of an anatomia animata (Montiel, 2008a, pp. 152-158). Such dream begins to take shape in the years in which Goethe writes Faust and E.T.A. Hoffmann produces his tales about automatons, including the well-known Der Sandmann- The Sand Man. It seems to me that the transition from the old method to the new one is precisely in that tale, as well as Hoffmann's critique to the entire Promethean project.

Let us remember the scene that made Freud lose track and take a turn towards the idea of castration complex in his forced interpretation of this tale (Montiel, 2008b, pp. 214-219). Little Nathanael decides to hide in the kitchen one night to see what his father 
and Coppelius do together, and he discovers that they carry out a sort of alchemy -in as far as their secret task involves metals worked under fire, in a hearth hidden behind the folding doors of a cupboard. The child thinks that the hearth serves the purpose of producing sparks that look like human heads. A cry of terror reveals his hiding place and he runs the risk of being sacrificed by Coppelius in favor of his dubious work, since he intends to pluck out his eyes to give them to his creatures. However, given the father's begging for forgiveness, the lawyer contents himself with "studying" the functioning of the child's hands and feet joints, by dislocating them painfully. ${ }^{21}$

Coppelius and Nathanael's father try to create a homunculus; that is presumed by their work near the hearth and the appearance of sparks that resemble human heads without eyes, which motivates Coppelius's dissatisfied and barbaric complain: "Eyes here! Eyes here!". And, since alchemy does not achieve its objective, the satanic lawyer turns towards mechanics - "but we will at any rate examine the mechanism of the hand and the foot" (Hoffmann, 1985, p. 17), seemingly resigned to move from the homunculus to the animated dummy, although this new field does not seem to be within his competence, as it is shown by his comment on the sadistic experiment carried out on the child's body, "That's not quite right altogether! It's better as it was! -The old fellow knew what he was about" (Hoffmann, 1985, p. 18).

For me, these two pages of Hoffmann are exemplary in the sense of the abandonment of an old methodology that has proved to be useless for a new one, undoubtedly less ambitious, but more in agreement with the materialistic choice made by the dominant way of thinking that ran throughout modernity. Only one year after the publication of this tale by Hoffmann, ${ }^{22}$ Frankenstein or the Modern Prometheus, by Mary Wollstonecraft Shelley, comes out. In Shelley's work, the chimera of the creation of a human body made out of anatomical parts is crystallized..$^{23}$ And in both stories, which share the characteristic of being extremely critical of that chimera, the rejection of the feminine element plays an important role. In the case of Nathanael, the abandonment of Clara, ${ }^{24}$ his girlfriend, for Olimpia, which is precisely an automaton doll. Regarding Frankenstein, the feminine side is rejected when the Promethean doctor refuses to fulfill his creature's demand for a female partner. However, something new emerges in the case of Hoffmann. Nathanael's attitude towards the pair Clara-Olimpia illustrates what, according to current psychologists, constitutes the root of the main psychical pathology of our time, i.e., narcissism, since Olimpia stands for a mere reflection, devoid of criticism, of the idea that Nathanael has formed of himself (Montiel, 2008b, pp. 219-221).
I am not going to expand on this subject, because I have addressed it thoroughly in the preceding works. In any case, I wish to remark that, the same as the homunculus, the automaton also gave rise to a certain reaction which Hoffmann provided evidence of. One reaction came from animal magnetism, which appears as a counter figure of mechanistic reductionism, both in the history of culture and medicine, and in Der Sandmann and other works by the same author, especially Die Automate (1814) - Automata (Montiel, 2008a, pp. 161-167).

Animal magnetism ${ }^{25}$ rescued the patient from the absolute submission to the holder of wisdom - and power-, i.e., the doctor, through the knowledge of their own body, their own disease and healing attributed to the somnambulist; it rescued the woman as a subject of her own life and her diseases; and it rescued the doctors - the ones that decided to adopt it - from the one-sided submission to the rational, clear, Apollonian. Gotthilf Heinrich von Schubert, doctor and nature philosopher, clearly understood it when he wrote the following in his Geschichte der Seele -History of the Soul:

Those who know the poverty and despair of this stage of humankind and of the peoples will understand with no effort the effect that the discovery of the so-called animal magnetism, and all the phenomena linked to it, has exerted on our time. Materialism would like to reject amid disparaging laughter the whole realm of these phenomena, considering it a night dream. But in the dream and in the night there exists a frightening force that does not allow itself to be expelled nor denied (Schubert, 1833, p. 382).

However, this rescue was ephemeral. Materialism recovered from the magnetic rebellion, and the romantic rebellion in general, and the soul had to wait for its problematic rescue almost one more century. Problematic, I say, because nothing is more evident than the fact that the Promethean endeavor of a creation without mother remains alive among us and enjoys, in general, higher regard than the demand of something that sounds as outdated as "soul".

Nowadays, genomics have taken the baton of the Promethean opus. However, let us not deceive ourselves; the metaphor on which it is based is only a mechanical issue. What is done with the chromosomes and parts of them is referred to as "bricolage" by those who execute it, and the ones who carry out the process are machines -extraordinarily powerful computers. And in this "genetic engineering" we estimate our current health expectancy, much more than in a rescue of the soul that is not scientific at all. And we contemplate our body from that point of view, from which the elusive and im- 
ponderable is irrelevant. Without mother. Without woman. Without psyche.

\section{EPILOGUE: FROM ANNIHILATION TO THE ABSENCE}

But perhaps there is a place for hope. The last manifestation of the figure of the automaton in literature is The Great Portrait (1960), by Dino Buzzati. In this novel, the automaton does not seem to be such thing, since it does not copy the human body. It is a huge construction, practically a little city, equipped with all the technological advances, especially electronic ones. Disturbing, as well as its creator. Only at the end of the story we get to know that, with that construction, its author intended to recuperate the soul -or the psyche- of his beloved lover, that is, the woman, the female psyche, in an automaton that does not copy the body anymore because that is not what his creator misses the most.

\section{NOTES}

1 A book whose title and subject are very similar to those of this article has been published recently: (Newman, 2004). It has been very helpful to me in some parts of my work, but its general orientation is quite different from mine.

2 In a personal capacity, given my insufficient knowledge of other cultures, I dare not take Bettina L. Knapp's line, although I transcribe it in any case and I believe it to be reliable. (Knapp, 1979, p. 4).

3 This is the way Nietzsche refers to him at the beginning of The Birth of Tragedy: (Nietzsche, 1999, pp. 35-36).

4 See, for example, the decisive role that the book by Mandressi, 2003, had as a starting point in my reflection (Montiel, 2008a, 152-158).

5 "Soul making" implies the idea that the soul must be built up, updated, made present and develop on a constant basis. It is not something given once and for ever.

6 This is one of the fundamental theses of the work I refer to which is explicitly addressed - and exemplified-in the chapter devoted to "The Suffering of Impossible Love" (pp. 97-107), as well as its interpretation of masochism (pp. 142-148).

7 "... what the female would contribute to the semen of the male would not be semen but material for the semen to work upon". Quoted by Hillman, (1972), p. 228.

8 "Compared with male seed, he finds the female to be 'thinner', 'colder', of 'higher viscosity', 'weaker', 'quantitatively less' and finally of an inferior tonus". In addition, Galen has a negative attitude towards the fact that female genitalia, similar to the male ones, have not reached their maximum development, since they remained inside the abdomen. (Hillman, 1972, p. 238).

9 "It was universally believed in the Middle Ages as well as in the Greco-Roman world that the soul is a substance. Indeed, mankind as a whole has held this belief from its earliest beginnings, and it was left for the second half of the nineteenth century to develop a "psychology without the soul". Under the influence of scientific materialism, everything that could not be seen with the eyes or touched with the hands was held in doubt (...) We are certainly not justified in saying that philosophy or natural science has brought about this complete volte-face. There were always a fair number of intelligent philosophers and scientists who had enough insight and depth of thought to accept this irrational reversal of standpoint only under protest (...) Let no one suppose that so radical change in man's outlook could be brought about by reasoned reflection, for no chain of reasoning can prove or disprove the existence of either mind or matter" (Jung, 1969 vol. 8, pp. 649-650).

10 However, this statement is surprising in as far as a few pages further on he links the figures of Faust and Prometheus, "Prometheus, Job, Faust: three stations in one, and the same human tension, that of a revolt of man against his own condition" (p. 17).

11 Johannes Faustus, 1480-1540 (Neher, 1987, p. 14). According to Knapp, Georg Faust and Johann Fust could enter the equation. The former was a so-called magician against whom abbot Trithemius warns mathematician and astrologist Johann Virdung (1507) by letter. On the other hand, Johann Fust, from Mainz, ca. 1466, was one of the potential inventors of the printing press. In the latter case, the Church's fear of the printing press cannot be ignored (Knapp, 1979, pp. 141-142)

12 The author points out that Scholem does not give any credit to the alleged authorship of the Jewish text, which, in my opinion, would make it analogous to Volksbuch; in some sense anonymous, collective.

13 The importance of the Christianized Cabala in the higher culture of the late Middle Ages and early Renaissance has been defended in a study that is already classic (Yates, 1979). The hypothesis of the Golem as an antecedent of the homunculus is rejected by Frick, 1964, but not in a decisive way, in my opinion.

14 Newman shares this view (Newman, 2004, p. 199).

15 This does not prevent that, in essence, Paracelsus, as a son of his time, shares the belief in female inferiority (Hillman, 1972, p.246).

16 The dialogue between the two philosophers of nature, Thales and Anaxagoras, reflects the contemporary discussion between the advocates of the theories about the origin of continents and the life developed in them; the "Neptunist" posture, represented by Thales and defended by Goethe, and the "Plutonist" one, represented in this case by Anaxagoras (Knapp, 1979, p. 147).

17 The two milestones that mark the territory are Psychologie und Alchemie (1944) and Mysterium Coninctionis (1955-56), vols. 12 and 14 (I, II and III) respectively, from the quoted edition of Collected Works. To these two works we need to add the texts put together in Vol. 13, Studien über alchemistische Vorstellungen, some others found in Vol. 9, Aion (1951) and Die Psychologie der Übertragung (1946), in Vol. 16, Praxis der Psychotherapie.

18 "The eternal feminine/ attracts us to the highest".

19 I cannot leave aside, however, the well-known air of superiority of Goethe towards women; I simply want to remark that, at a deep level, his psychology was more sensitive to the feminine value than in most of his contemporaries. 
20 This author goes even further in her interpretation of Jungian psychology, "Homunculus (...) represents spirit as well. Mephistopheles, on the other hand, stands for instinct and body, whereas Faust symbolizes the power of soul" (p. 146). I do not disagree with this statement, although it seems to me a bit simplifying, especially regarding Faust, whose importance consists of just being a human being, stage of the drama among those three levels, i.e., spirit, soul and body, understood, of course, as Jung proposed it.

21 A Hoffmann scholar has linked this scene with another one that was exposed in a comedic way, but indeed also disquieting terms. It is the account of a dream by the character of painter Bickert in The Magnetizer, in which Bickert describes how he saw himself as a watermark in a piece of paper, and how a bad poet, whose name is not mentioned, played with him by messing up his figure and drawing his limbs in the most implausible places of his body. It is noteworthy that, in order to refer to him without mentioning his name or foolishly repeating "the bad poet", Bickert calls him "the anatomic Satan" in one occasion. This is an argument to add

\section{BIBLIOGRAPHY}

Arnim, Ludwig Achim von (1982), Isabel de Egipto o el primer amor de Carlos V, Barcelona, Bruguera.

Buzzati, Dino (1960), I/ grande ritrato, Milano, Mondadori.

Campbell, James (1986), The Masks of God: Occidental Mythology, New York, Penguin Books.

Drux, Rudolf (1986), Marionette Mensch. Ein Metaphernkomplex und sein Kontext von E.T.A. Hoffmann bis Georg Büchner, München, Fink.

Frick, Karl (1964), "Zum Homunculus-Problem”, Sudhoffs Archiv 48, pp. 174-177.

Goethe, Johann Wolfgang (1999), Faust, (Sämtliche Werke), Frankfurt, Deutscher Klassiker Verlag.

Hillman, James (1972), The Myth of Analysis, Evanston, Northwestern University Press.

Hoffmann, Ernst Theodor Amadeus (1985), "Der Sandmann". In: Nachtstücke (Sämtliche Werke), Frankfurt, Deutscher Klassiker Verlag, pp. 11-49.

Jung, Carl Gustav (1969) The Structure and Dynamics of the Psyche, Collected Works, vol.8, London, Routledge.

Jung Carl Gustav (1970), Mysterium coniunctionis, Collected Works, vol. 14, London, Rutledge.

Knapp, Bettina (1979), The Prometheus Syndrome, Troy, New York, The Whitston Publishing Company.

Mandressi, Rafael (2003), Le regard de l'anatomiste. Dissections et invention du corps en Occident, Paris, Seuil.

Montiel, Luis; González de Pablo, Ángel (Coords.) (2003), En ningún lugar. En parte alguna. Estudios sobre la historia del magnetismo animal y del hipnotismo, Madrid, Frenia. to those pointed out by Mandressi, 2003, pp. 228-239, on behalf of the ubiquity of anatomy in modern imagination (Sauer, 1983, p. 210). Similarly Drux, (1986), p. 86

22 Der Sandmann was published in 1817, although it was written in 1815.

23 Significantly, the author, contrary to all the others who have adapted his story for the cinema, wisely refuses to explain the way in which all that dead matter is brought to life.

24 I cannot attempt to analyze this character, which is quite ambiguous from the point of view of the values that Hoffmann deals with in his story. However, maybe for that same reason, she is clearly human.

25 What follows is a synthesis of the research carried out in my following works: Montiel (2003), (2006a, b y c), (2008c y d), (2009 a y b).

Montiel, Luis (2006a), Daemoniaca. Curación mágica, posesión y profecía en el marco del magnetismo animal romántico, Barcelona, MRA.

Montiel, Luis (2006b), "Síntomas de una época: Magnetismo, histeria y espiritismo en la Alemania romántica", Asclepio, LVIII (2), pp. 11-38.

Montiel, Luis (2006c), “Magnetismo romántico. El paciente. La mujer. La república”, Dynamis, 26, pp.125-150.

Montiel, Luis (2008a), "Sobre máquinas e instrumentos (I): el cuerpo del autómata en la obra de E.T.A. Hoffmann", Asclepio, LX (1), pp. 151-176.

Montiel, Luis (2008b), "Sobre máquinas e instrumentos (II): El mundo del ojo en la obra de E.T.A. Hoffmann". Asclepio, LX (2), pp. 207-232.

Montiel, Luis (2008c), Magnetizadores y sonámbulas en el romanticismo alemán, Madrid, Frenia.

Montiel, Luis (2008d), “La primera 'rebelión del sujeto': la medicina magnética del romanticismo alemán". En: Ortiz Gómez, Teresa; Olagüe de Ros, Guillermo; Rodríguez Ocaña, Esteban; Menéndez Navarro, Alfredo; Gil García, Eugenia; Luna Maldonado, Marco Antonio; Sevilla Olmedo, Maite; Gómez Núñez, Antonio J. (Coords.), La experiencia de enfermar en perspectiva histórica. XIV Congreso de la Sociedad Española de Historia de la Medicina, Granada, 11-14 de junio de 2008, Granada, Ed. Universidad de Granada, pp. 153-157.

Montiel, Luis (2009a), “Une révolution manquée: le magnétisme animal dans la médecine du romantisme allemand", Revue d'histoire du XIXe siècle, 38 (1), pp. 61-77.

Montiel, Luis (2009b), "Der Kampf mit dem Dämon. Daemoniaca aus der Perspektive des Jenaer Professors der Medizin Dietrich Georg Kieser (1779-1862)“. En : Wolf-Braun, Barbara. (Hrsg.) Medizin und Okkultismus, Frankfurt am Main, Schriftenreihe des Senckenbergischen Instituts für Geschichte und Ethik der Medizin, Bd. 2, pp. 22-44.

Montiel, Luis (2010), "Más allá de la lujuria: la procreación sin madre (el homúnculo, el gólem y el autómata)". En: Navarro, Paloma; Jiménez, Ana; Martínez, Unai; González, Cristina (eds.), 
Lujuria y deseo: un avance y una mirada atrás. Sociedad de Historia y Filosofía de la Psiquiatría, pp. 27-44.

Neher, André (1987), Faust et le Maharal de Prague. Le mythe et le réel, Paris, Puf.

Newman, William R. (2004), Promethean Ambitions. Alchemy and the Quest to Perfect Nature, Chicago and London, The University of Chicago Press.

Nietzsche, Friedrich (1999), "Die Geburt der Tragödie". En: Kritische Studienausgabe (Hrsg. Von G. Colli \& M. Montinari), Berlin \& New York, DTV \& de Gruyter.

Paracelsus, Theoprastus (1982), Werke, Basel, Schwabe.

Sauer, Liselotte (1983), Marionetten, Maschinen, Automaten: Der künstliche Mensch in der deutschen und englischen Romantik, Bonn, Bouvier.
Scholem, Gershom (1953), "Die Vorstellung vom Golem in ihren tellurischen und magischen Beziehungen", Eranos, 22, pp. 235-289.

Schubert, Gotthilf Heinrich von (1833), Die Geschichte der Seele, Stuttgart und Tübingen, Cotta.

Yates, Frances (1979), The Occult Philosophy in Elizabethan England, London, Routledge.

Wyder, Margrit (2005), "Es wird ein Mensch gemacht. Faust II und Frankenstein". In: Stulz, Peter; Nager, Frank; Schulz, Peter (eds.), Literatur und Medizin, Zürich, Chronos, pp. 53-68. 